\title{
Strategic human resources management and hotel performance
}

\section{A influência da gestão estratégica de pessoas no desempenho hoteleiro}

Luciano Aparecido Nascimento Machado

IFSC - Instituto Federal de Santa Catarina, Brazil, nascluciano@gmail.com

Deosir Flavio Lobo de Castro Junior

IFSC - Instituto Federal de Santa Catarina, Brazil, deosir@ifsc.edu.br

\section{Tiago Savi Mondo}

IFSC - Instituto Federal de Santa Catarina, Brazil, tiago.mondo@ifsc.edu.br

Elvis Silveira-Martins

UFPel - Universidade Federal de Pelotas, Brazil, elvis.professor@gmail.com

\section{Jean Carlos de Abreu}

Faculdade Estácio de Sá de Santa Catarina, Brazil, jeancarlosdeabreu@gmail.com

\begin{abstract}
This study sought to verify strategic human resources management's influence on hotel performance by analysing data on managers of hotels located in Grande Florianópolis, Brazil. Bibliographical research was conducted to provide a theoretical framework to support the analysis, and a descriptive methodology approach based on the positivist paradigm was applied. The proposed model was subjected to exploratory factor analysis, confirmatory factor analysis and structural equation modelling. The sample consisted of 70 hotel managers, and the data were collected with a closed-ended questionnaire. The results show that, of the 32 variables studied, 13 variables are connected to high performance in medium-sized hotels in Grande Florianópolis. In addition, the analyses confirmed the validity of the proposed model, in which strategic human resources management is directly related to hotel performance. The findings include that employee training and development, as well as workplace structuring, are strategic human resources management practices essential to achieving higher performance.
\end{abstract}

Keywords: Strategic human resources management, hotel performance, hotel industry, structural equation modelling.

\section{Resumo}

O presente estudo teve por objetivo verificar a relação das práticas de gestão de pessoas com o desempenho em hotéis de Florianópolis. Para a consecução deste objetivo, foi realizado inicialmente uma pesquisa bibliográfica, encontrando fundamentação teórica para suportar esta hipótese. No que tange aos procedimentos metodológicos, caracterizase por ser descritiva. O modelo proposto foi analisado pelos critérios de análise fatorial exploratória; análise fatorial confirmatória e modelagem de equações estruturais. A amostra foi composta por 70 gestores hoteleiros e o instrumento foi o questionário fechado. Como os principais resultados, destaca-se que das 32 variáveis estudadas, 13 variáveis possuem relação com o melhor desempenho na hotelaria de hotéis médios, na Grande Florianópolis. Como principais conclusões a pesquisa confirmou o modelo proposto no qual a gestão estratégica de pessoas tem relação direta com o desempenho hoteleiro. Mostrou que das práticas essenciais de gestão de pessoas nessa realidade estão treinamento e desenvolvimento de funcionários, bem como a estruturação do ambiente do trabalho.

Palavras-chave: Gestão de pessoas, desempenho hoteleiro, hotelaria, modelo de equações estruturais.

\section{Introduction}

Tourism is a contemporary and worldwide social phenomenon that involves several sectors, such as transportation, lodging, food, among others. This means that it should not be studied in isolation and requires a more holistic view. Although there are different definitions for tourism, these definitions have in common the notion of temporary displacement of people from their permanent place of residence (Meyer, 2008; Corrêa, Mariani, Veloso \& Satolani, 2011).

In times of dynamic and highly diversified markets, modern tourism, and its segmentations have gained significant importance in the leading developing economies, generating jobs and income. Today global tourism is an essential product of world trade, surpassing - or equaling -the volume of business, the export of oil, food or automobile (WTO, 2017a).

According to the World Tourism Organization (UNWTO), tourism is undeniably an essential economic activity, contributing to $10 \%$ of the Gross Domestic Product (GDP) worldwide, in direct, indirect and induced effect. In addition, tourism is responsible for 1 in every 11 job positions (UNWTO, 2017b).

In Brazil, the Ministry of Tourism defines the activity according to the UNWTO, as "activities of people travelling to and staying in places outside their usual environment for not more than one consecutive year for leisure, business or other purposes" (MTUR, 2017a, p4). The Ministry of Tourism in Brazil understands that, in order to better plan, organise and manage, it is necessary to segment tourism according to its purposes. Some of these are: Social Tourism, Ecotourism, Cultural Tourism, Sports Tourism, Sun and Beach Tourism, Business and Events Tourism, Rural Tourism and Health Tourism.

The tourism sector in Brazil, according to a study conducted by the World Travel and Tourism Council (2017a), moved R\$ 530.5 billion in 2016, which represents $8.5 \%$ of the country' GDP and indicates expected growth of $0.5 \%$ in 2017 . This puts Brazil as 
the $11^{\text {th }}$ economy of tourism in the world. In addition, the study showed that tourism participated significantly in job creation, with 7 million new positions in 2016 , or $7.8 \%$ of total jobs created in the country (WTTC, 2017a).

Although tourism is an important sector of the economy, it should be understood comprehensively and systemically, as an activity that does not occur in isolation (Corrêa et al., 2011). According to Barros, Silva, Granero, \& Braga Filho (2008), this activity develops through complex sets of relationships, social, economic and environmental. In terms of social relations, it is possible to observe the interdependence between residents and visitors/tourists. As for the economic relations, they are observed in the destination as well as during travel from the tourists' origin to the destination, which can involve transportation, lodging and food, or the purchase of products and souvenirs. Finally, in terms of environmental relations, there are cultural dimensions and the physical environment where the activity takes place (Barros, et al., 2008; SEBRAE, 2010).

According to the Brazilian Ministry of Tourism, the hotel industry is responsible for 350,000 formal and 1.5 million indirect jobs in Brazil, indicating the importance of this industry within the tourism, social and economic sector. (MTUR, 2017b $\mathrm{p} 4)$. The South Region of Brazil - where the region focus of this research is located - is responsible for $18.7 \%$ of the formal and indirect jobs in the hotel industry and, according to a national comparison study, is the third most important out of the five Brazilian regions (DIEESE, 2013).

Within the wide range of elements of the tourism sector, hotels have a fundamental role in its development. Barreto (2007) mentions that the hotel industry began as a complementary element of tourism. Since the twelfth century, inns were already seen by the European roads and gradually, countries like France and England implemented laws to regulate the activity. Corroborating the author, Campos and Gonçalves (1998) defends that the means of lodging are fundamental in the viabilization of the tourist activity and the lack of them can cause a region with great tourist potential to do not develop. In tourism market, the lodging facilities receive clients/guests and offer, apart from the lodging service, complimentary services such as leisure, food, tours, parking, internet, among others (Mondo \& Fiates, 2017).

Over the years the city of Florianópolis has expanded from the central area to other regions of the island (where the majority of the city's territory is located). These regions have received infrastructure and become tourist destinations (Lanziotti., 2008), counting on several hotel facilities.

In 2011, a research of the Brazilian Institute of Geography and Statistics (IBGE) showed the existence of 254 lodging facilities in the region. In 2016, this number increased by $72 \%$, to 438 establishments, providing 12,867 hotel units and 34,500 beds (IBGE, 2011, Floripa Amanhã, 2016).

As hotel business is based on services, the quality is determined by the client's perception of their experiences and expectations towards the service provided. Therefore, employees who provide these services are key for the business to meet the client's expectations, and managers have the complex task of motivating them (Castro Júnior, Gonçalo \& Rossetto, 2014; Barreto, Albuquerque \& Medeiros, 2014).

Thus, Strategic Human Resources Management in hotels deserves attention, because as well as managing the routine activities, it is crucial to develop a good work environment, reduce turnover, encourage positive attitudes and motivate employees to be able to render quality service (Petrocchi, 2002; Barreto et al., 2014; Santos \& Estender, 2016).

It is possible to say that for all companies, but especially in the hotel industry, there are challenges such as the recruitment and selection, the exhaustive work schedule, and, especially, the maintenance of an efficient team. According to data from 2013, most of the workers in this field are working for less than 1 year $(41,4 \%)$ in the job, and only $18.6 \%$ are working for more than five years, which means that turnover is an important obstacle for hotel management (DIEESE, 2013).

Castro Júnior (2013) developed and validated a service differentiation scale for the executive hotel industry, where three dimensions are presented: (i) People, (ii) Processes, and (iii) Environments. The author concluded that the differentiation of services has a positive and significant relationship, whether it is a direct relationship with the performance, or mediating the relationship between dynamic market capacities and hotel performance.

Considering the above, one question arises: Which practices presented by the theory of Strategic Human Resources Management are being used by managers in hotels of the Greater Florianopolis region and what is their relation to hotel performance?

This research aims to verify the practices of Strategic Human Resources Management in the hotel industry and to measure their relation with the performance of hotels in this region of Brazil.

\section{Strategic human resources management in the hotel industry}

In order to understand activities related to Strategic Human Resources Management, it is worthwhile referring to Lacombe (2004), who defines Strategic Human Resources Management as a collection of efforts aimed at practices such as planning, organising, leading, coordinating and controlling activities of a group of individuals that seek results in common. These practices are indicated for all types of lodging facilities.

In hotel administration, practices of Strategic Human Resources Management - due to the fast environmental, and principally economic and technological, changes - reached a strategic status. The set of these successful practices aims to increase the competitiveness of hotels, as well as to add value to the product/service (Camargos \& Dias, 2010; Ferreira, 2013). 
Strategic management, in the organisational context, is a method chosen by the organisation so that its objectives are achieved, the vast majority, in the long term. It is connected to the planning, investment and development of the capacities and competencies of the collaborators (Pimentel, 2016).

From a broad view of the organisation, organisational knowledge - composed of tacit and explicit knowledge started to be recognised as the 'engine' of real competitive advantage, including in the hotel industry. In this industry and considering this context, people are those who have tacit knowledge and recognise that it leads to a new paradigm: human capital. Therefore, the employee is recognised as an essential asset within the hotel organisation, with a determining role for high organisational performance and opposing the idea that people are mere resources available to be exploited, and have low strategic value (Bolgar, 2001, Pimentel, 2016).

Thus, Strategic Human Resources Management (SHRM) started to be adopted in organisations. The decision to adopt SPM, however, must be defined together with the organisation's strategic policy and drawn from the company's business plan, which facilitates that ideas and actions will be aligned. In the hotel industry, the relationship between the various sectors of the business and their agents within the organisation is crucial. These relationships are mostly dependent on human behaviour. Thus, it is possible to observe the direct relationship between Strategic Human Resources Management and organisational performance (Aryee \& Budhwar, 2008; Pimentel, 2016; Echeverria, Crepaldi \& Bianchi, 2017).

Strategic Human Resources Management in the hotel industry can be perceived as the process of managing the diversity of activities related to the employees, aiming at the implementation and maintenance of the competitive advantage of the hotel. In this context, Strategic Human Resources Management in the hotel industry involves in particular: i) recruitment; ii) selection; iii) training; iv) employee development; v) job structuring and remuneration policies; vi) benefits; vii) performance appraisal; and viii) structuring the workplace (Araújo \& Garcia, 2009; Pimentel, 2016).

Recruitment consists of the organisation's efforts to attract candidates to their positions. It takes into consideration requirements pre-established by the company's sectors. Selection process refers to identifying the profile of candidates recruited, their knowledge and skills that may contribute and add value to organisational knowledge. It is worth mentioning that employee turnover in an organisation may indicate a failure in this selection process and entail costs and negative influences on the organisational climate (Assis, 2009; Santos \& Estender, 2016; Echeverria et al., 2017).

Training is essential for the company's development and to disseminate organisational knowledge. It seeks to improve the skills and enable employees to perform a given job/task. In order to be successful in training, the productive capacity of the employee and their predispositions to learning must be taken into account. In addition, adequate planning is necessary and should begin with the diagnosis of the need, the preparation of a training plan, be implemented consistently and conducted efficiently. Finally, the process needs to be evaluated, validated, re-adjusted or discarded (Araújo, 2001; Ferreira, 2013; Echeverria et al., 2017).

As for job structuring and remuneration policies, they are activities that involve describing the tasks for each position and the limits of the worker responsibilities, as well as determining the remuneration to be applied for the jobs offered. Although these elements are not the only influencers of personal motivation, they are paramount for them to be well structured so that the tasks attributed can occur effectively. A clear and defined scope provides support for both performance appraisals and career planning. Also, through job structuring and remuneration policies, it is possible to manage other activities such as hiring, granting promotions and retaining talent (Araújo \& Garcia, 2009).

When conducting the activity of job structuring, it is essential to think beyond the scope of work and take into account the behaviours of those who will execute it. This allows companies not only to supervise the tasks, as it was in Taylor's model but also to develop the individuals through their work (Assis, 2009).

The salary is the payment for the execution of a job, and its main objective is to establish the commitment of work between the parties. However, it should not be seen as the only form of remuneration, but rather as a component of a more robust system also composed of benefits. In this way, remuneration is seen as a differential and adds value to the organisation. Ideally, it should be in line with the employee's expectations, be able to meet their needs, and be appealing in order to attract and retain talent (Gheno \& Berlitz, 2011; Barreto et al., 2014; Nichele, Stefano \& Raifur, 2015).

In hotels where Strategic Human Resources Management activities are aligned with organisational strategies, there is a broader view of the employees' needs and the organisations tend to offer benefits that complement remuneration (Nichele et al., 2015).

The performance appraisal seeks to measure the contribution of the employee in the 'value' produced by the organisation and allows the employee to have greater control of the quality in the production. Because it is a subjective process, performance appraisal must be very well planned. The actions proposed from the results of this activity must be substantiated and presented clearly. The outcomes of appraisals can be used in the preparation of training and to allocate personnel around the functions or to grant promotions in the organisational hierarchy according to the career plan (Assis, 2009; Castro Júnior, Gonçalo, Rossetto \& Deluca., 2016).

A healthy workplace for the World Health Organization "is one in which workers and managers collaborate to use a continual 
improvement process to protect and promote the health, safety and well-being of all workers and the sustainability of the workplace" (WHO, 2010, p.06).

The production process of the organisation passes through the workplace, so promoting it healthily, should be a strategic decision. Companies that seek quality invest in tools, processes and people, capable of delivering the proposed value. They are among the most successful and competitive and have a high rate of employee retention (WHO, 2010; Barreto et al., 2014).

\section{Methodology}

The study adopted a quantitative exploratory approach, which can be measured - as reminded by Fonseca (2002) - as well as allowing more significant knowledge of the problem to be studied. This approach uses a sample presenting characteristics that represent participants in the research, and the results are recognised and validated as a real expression of the entire target of the research.

Descriptive research was used as a complement to the exploratory research, in order to enable the description of phenomena and to compare and evaluate the developments of the object of study.

For the development of the exploratory theoretical framework, the bibliographic method was adopted, using scientific material already published and available for research.

As for the object of study, the research focused on mediumsized hotels located in the region of Greater Florianópolis, in the State of Santa Catarina, Brazil. Data was collected using statistically validated questionnaires - an instrument that fully served the needs of the study - applied to hospitality managers operating in these hotels.

In order to verify the practices of strategic Strategic Human Resources Management in the hotel industry, this research used the scale validated by Barreto (2011), who studied the strategies of Strategic Human Resources Management and organisational performance in the hotel industry, focused on the role of the organisational capabilities. As for the performance of the hotels, the research used the scale developed by Carvalho (2011) and validated by Castro Júnior (2013).

The data collected and analysed were obtained through a survey approach, using a questionnaire with direct questions (what, why, how much), in which the researcher cannot or is not interested in controlling variables. (Freitas, Oliveira, Saccol, \& Moscarola, 2000). The methodology can be classified as descriptive because it seeks to identify attitudes and opinions in the participants in the research (units of analysis) (Freitas et al., 2000).

The universe chosen for this research is comprised of mediumsized hotels that are part of the 454 lodging facilities (according to a mapping carried out by SEBRAE/SC in 2013) established in the region of Greater Florianópolis in the State of Santa Catarina, Southern Brazil. The choice for medium-sized hotels was made considering the characteristics of these establishments, considered favourable for this research because of the reasonable number of employees and the environment that demands Strategic Human Resources Management practices.

Out of the medium-sized hotels, a sample of 70 respondents was reached. Previously, a survey of the hotels in the region was conducted, using data available on the internet and developing a road map in order to approach them in the period between 0131 October 2017. The result was obtained considering the research time and budget, as well as the availability of the participants (convenience sampling). Thus, this study is characterised as non-probabilistic research. (Freitas et al., 2000).

Regarding the data analysis and to test the proposed model, the data were evaluated by: i) exploratory factor analysis (EFA); ii) confirmatory factor analysis (CFA), and iii) structural equation modelling. The measures and minimum values expected for the EFA are presented in Table 1.

Table 1 - Measures and minimum values expected for EFA

\begin{tabular}{|l|c|}
\hline \multicolumn{1}{|c|}{ Measures } & $\begin{array}{c}\text { Expected minimum } \\
\text { values }\end{array}$ \\
\hline Commonalities & 0.50 \\
\hline Measure sampling adequacy (MSA) & 0.50 \\
\hline Sample reliability (Cronbach's alpha) & 0.70 \\
\hline Bartlett's test of sphericity & $p \leq 0.05$ \\
\hline Inter-items correlation & 0.30 \\
\hline Item-total correlation & 0.50 \\
\hline Factor loading (for n60) & 0.70 \\
\hline Source: Adapted from Hair Jr, Anderson, Tatham \& Black, (2009).
\end{tabular}

In addition, the measures and minimum values expected for the CFA and SEM are presented in Table 2 (chi-squared, chi-squared degrees of freedom, p, CFI - Comparative Fix Index, TLI Tucker-Lewis Index and Root Mean Square Error of Approximation).

\section{Table 2 - Expected results for CFA and tests of model} adjustment

\begin{tabular}{|l|c|}
\hline \multicolumn{1}{|c|}{ Indicator } & Expected result \\
\hline X2 (chi-squared) & $\mathrm{P}>\alpha$ \\
\hline X2/Degrees of Freedom (chi-squared/DF) & $<3.000$ \\
\hline $\mathrm{P}$ & $>0.050$ \\
\hline $\mathrm{CFI}$ & $>0.900$ \\
\hline TLI & $>0.900$ \\
\hline RMSEA & $<0.100$ \\
\hline
\end{tabular}

\section{Data analysis}

\subsection{Exploratory Factor Analysis}

Data was collected using a self-report questionnaire and organised, codified and processed using an Excel ${ }^{\circledR}$ worksheet, Statistical Package for the Social Science (SPSS ${ }^{\circledR}$ ) 21 and Analysis of Moment Structures AMOS ${ }^{\mathrm{TM}}$ ) 21.

The assessment of unidimensionality was obtained using SPSS ${ }^{\circledR}$ 21 , applying the method of factor extraction through principal components analysis (PCA). As for the construct 'Strategic 
Human Resources Management', the study used the scale validated by Barreto (2011), which presents 33 variables (Table 3). The construct 'Hotel Performance' used Carvalho's scale (2011), validated by Castro Júnior (2013), which takes into consideration the variables HOP1 - Total sales; HOP2 - Average occupancy rate; HOP3 - Profit margin on total sales; HOP4 Average daily rate; HOP5 - Sales per unit; HOP6 - Average cost per occupied room.

Table 3 - Variables of the construct - Strategic Human Resources Management

\begin{tabular}{|r|l|}
\hline SHRM1 & Investing in people education, training and development \\
\hline SHRM2 & Promoting a better workplace \\
\hline SHRM3 & Facilitating the achievement of organisational goals \\
\hline SHRM4 & Investing in programs to retain talents \\
\hline SHRM5 & Promoting efficient administration \\
\hline SHRM6 & Stimulating the commitment of people with the organization \\
\hline SHRM7 & Disseminating and strengthening organisational culture \\
\hline SHRM8 & Promoting creativity in pursuing continuous improvement \\
\hline SHRM8 & Investing in the development of managers and leaders \\
\hline SHRM10 & Stimulating careers development and management \\
\hline SHRM11 & Promoting result oriented Strategic Human Resources Management \\
\hline SHRM12 & Promoting organisational learning \\
\hline SHRM13 & Achieving operational excellence in Strategic Human Resources Management services \\
\hline SHRM14 & Promoting and practising social and environmental responsibility \\
\hline SHRM15 & Promoting continuous improvement of organisational processes \\
\hline SHRM16 & Developing organisational and individual competencies \\
\hline SHRM17 & Attracting competent employees \\
\hline SHRM18 & Developing a culture of high performance \\
\hline SHRM19 & Promoting employees integration and teamwork \\
\hline SHRM20 & Investing in procedures standardisation and control \\
\hline SHRM21 & Promoting variable remuneration in the long term \\
\hline SHRM22 & Developing effective and transparent communication \\
\hline SHRM23 & Preparing the organisation to face future challenges \\
\hline SHRM24 & Implementing or restructuring processes of salary and benefits \\
\hline SHRM25 & Identifying and implementing best practices in Strategic Human Resources Management \\
\hline SHRM26 & Facilitating organisational changes \\
\hline SHRM27 & Recognising and rewarding people \\
\hline SHRM28 & Stimulating delegation and autonomy (empowerment) \\
\hline SHRM29 & Promoting diversity and inclusion \\
\hline SHRM30 & Promoting knowledge management \\
\hline SHRM31 & Promoting and supporting employees' initiatives \\
\hline & Investing in the development of new technology and working methods \\
\hline & Other: \\
\hline
\end{tabular}

Source: Barreto (2011).

\subsubsection{Exploratory Factor Analysis - Construct 'Strategic Human Resources Management'}

For the commonality test for the construct 'Strategic Human Resources Management', the approved variables were SPM8, SPM21; SPM22; SPM23; SPM24; SPM25; SPM26; SPM27;
SPM28; SPM29; SPM30; SPM31 and SPM32, all variables being above the minimum expected (0.50), with the lowest value for the variable SPM8 (0.607), which is considered acceptable in this test. Table 4 shows the commonality values for each variable.

Table 4 - Commonalities -Strategic Human Resources Management

\begin{tabular}{|c|c|c|c|c|c|c|c|c|c|c|c|c|c|c|}
\hline SHRM8 & SHRM21 & SHRM22 & SHRM23 & SHRM24 & SHRM25 & SHRM26 & SHRM27 & SHRM28 & SHRM29 & SHRM30 & SHRM31 & $\begin{array}{c}\text { SHRM } \\
\text { SH }\end{array}$ \\
\hline 0.607 & 0.759 & 0.660 & 0.797 & 0.717 & 0.840 & 0.979 & 0.823 & 0.720 & 0.733 & 0.815 \\
\hline
\end{tabular}

For the measure of sampling adequacy (MSA) test, the variables approved were SHRM8, SHRM21; SHRM22; SHRM23; SHRM24; SHRM25; SHRM26; SHRM27; SHRM28; SHRM29; SHRM30; SHRM31 and SHRM32, all variables being above the minimum expected (0.50). The variable with the lowest value was SHRM28 (0.906) for anti-image correlation, which is considered acceptable in this test. Table 5 presents the values for MSA for each variable. 
Table 5 - Values for measure of sampling adequacy (MSA)

\begin{tabular}{|c|c|c|c|c|c|c|c|c|c|c|c|c|c|c|}
\hline & & SHRM8 & SHRM21 & SHRM22 & SHRM23 & SHRM24 & SHRM25 & SHRM26 & SHRM27 & SHRM28 & SHRM29 & SHRM30 & SHRM31 & SHRM32 \\
\hline \multirow{13}{*}{$\begin{array}{l}\text { Anti-image } \\
\text { Covariance }\end{array}$} & SHRM8 & 297 & ,016 &,- 009 &,- 063 & ,066 & ,022 &,- 071 &,- 009 & ,010 &,- 001 & ,016 &,- 090 &,- 019 \\
\hline & SHRM21 & ,016 & ,239 &,- 026 &,- 006 &,- 043 & ,028 &,- 016 &,- 026 &,- 034 &,- 013 & ,004 &,- 035 &,- 032 \\
\hline & SHRM 22 &,- 009 &,- 026 & 249 &,- 108 & ,023 &,- 006 & ,012 &,- 032 & ,023 &,- 011 &,- 018 & ,028 &,- 009 \\
\hline & SHRM23 &,- 063 &,- 006 &,- 108 & 147 &,- 044 &,- 006 & ,001 & ,013 & ,001 &,- 028 &,- 003 & ,000 & ,002 \\
\hline & SHRM24 & ,066 &,- 043 & ,023 &,- 044 & 158 &,- 031 &,- 035 &,- 036 & ,050 & ,038 &,- 022 &,- 003 &,- 052 \\
\hline & SHRM 25 & ,022 & ,028 &,- 006 &,- 006 &,- 031 & 109 &,- 051 &,- 009 & ,011 &,- 079 & ,008 &,- 025 &,- 006 \\
\hline & SHRM26 &,- 071 &,- 016 & ,012 & ,001 &,- 035 &,- 051 & 138 &,- 036 &,- 005 & ,030 &,- 012 & ,042 &,- 025 \\
\hline & SHRM 27 &,- 009 &,- 026 &,- 032 & ,013 &,- 036 &,- 009 &,- 036 & 134 &,- 078 &,- 007 & ,034 &,- 032 & ,027 \\
\hline & SHRM28 & ,010 &,- 034 & ,023 & ,001 & ,050 & ,011 &,- 005 &,- 078 & 191 &,- 029 &,- 049 &,- 013 &,- 028 \\
\hline & SHRM 29 &,- 001 &,- 013 &,- 011 &,- 028 & ,038 &,- 079 & ,030 &,- 007 &,- 029 & 174 &,- 035 &,- 002 & ,026 \\
\hline & SHRM 30 & ,016 & ,004 &,- 018 &,- 003 &,- 022 & ,008 &,- 012 & ,034 &,- 049 &,- 035 & 144 &,- 065 &,- 065 \\
\hline & SHRM31 &,- 090 &,- 035 & ,028 & ,000 &,- 003 &,- 025 &, 042 &,- 032 &,- 013 &,- 002 &,- 065 & , 163 & ,015 \\
\hline & SHRM 32 &,- 019 &,- 032 &,- 009 & ,002 &,- 052 &,- 006 &,- 025 & ,027 &,- 028 & ,026 &,- 065 & ,015 & ,239 \\
\hline \multirow{13}{*}{$\begin{array}{l}\text { Anti-image } \\
\text { Correlation }\end{array}$} & SHRM8 & ,910a & ,060 &,- 034 &,- 302 & ,305 & 121 &,- 351 &,- 043 & ,041 &,- 005 & ,075 &,- 409 &,- 071 \\
\hline & SHRM 21 & ,060 & ,970a &,- 108 &,- 032 &,- 220 & 172 &,- 091 &,- 146 &,- 157 &,- 064 & ,022 &,- 179 &,- 133 \\
\hline & SHRM 22 &,- 034 &,- 108 & ,929a &,- 564 & 116 &,- 039 & ,067 &,- 176 & , 105 &,- 053 &,- 097 & 139 &,- 036 \\
\hline & SHRM 23 &,- 302 &,- 032 &,- 564 & ,927a &,- 288 &,- 051 & ,005 & ,094 & ,005 &,- 177 &,- 020 & ,001 & ,011 \\
\hline & SHRM 24 & ,305 &,- 220 & 116 &,- 288 & ,906a &,- 235 &,- 236 &,- 247 & ,289 & ,230 &,- 146 &,- 021 &,- 269 \\
\hline & SHRM 25 & 121 & 172 &,- 039 &,- 051 &,- 235 & ,917a &,- 419 &,- 075 & ,076 &,- 572 & ,065 &,- 186 &,- 038 \\
\hline & SHRM26 &,- 351 &,- 091 & ,067 & ,005 &,- 236 &,- 419 & ,922a &,- 269 &,- 028 & 194 &,- 089 & ,278 & -138 \\
\hline & SHRM 27 &,- 043 &,- 146 &,- 176 & ,094 &,- 247 &,- 075 &,- 269 & ,925a &,- 491 &,- 046 & ,246 &,- 217 & 150 \\
\hline & SHRM 28 & ,041 &,- 157 & , 105 & ,005 & ,289 & ,076 &,- 028 &,- 491 & ,924a &,- 159 &,- 294 &,- 071 &,- 130 \\
\hline & SHRM 29 &,- 005 &,- 064 &,- 053 &,- 177 & ,230 &,- 572 & 194 &,- 046 &,- 159 & ,919a &,- 224 &,- 013 & 126 \\
\hline & SHRM 30 & ,075 & ,022 &,- 097 &,- 020 &,- 146 & ,065 &,- 089 & ,246 &,- 294 &,- 224 & ,928a &,- 421 &,- 352 \\
\hline & SHRM31 &,- 409 &,- 179 & 139 & ,001 &,- 021 &,- 186 & ,278 &,- 217 &,- 071 &,- 013 &,- 421 & ,922a & ,075 \\
\hline & SHRM 32 &,- 071 &,- 133 &,- 036 & ,011 &,- 269 &,- 038 & -138 & 150 & -,130 & 126 &,- 352 & ,075 & ,952a \\
\hline
\end{tabular}

Source: Research data (2017).

Regarding the sample reliability, the study conducted the 0.700 . The result obtained was 0.972 for Cronbach's Alpha and Cronbach's Alpha test, where the minimum expected result is for Standardized Cronbach's alpha, as shown in Table 6.

Table 6 - Values for Cronbach's Alpha for the construct 'Strategic Human Resources Management'

\begin{tabular}{|c|c|c|c|}
\hline Cronbach's Alpha & Standardized Cronbach's Alpha & Number of Items \\
\hline 0.972 & 0.972 & 13 \\
\hline
\end{tabular}

Source: Research data (2017).

For the Kaiser-Meyer-Olkin (KMO) test for sampling adequacy, thus being approved. Table 7 shows the values for KMO test the value found was 0.927 , which is above the minimum and Bartlett's sphericity.

expected (0.50), and the significance was lower than 0.05 ,

Table 7 - Values for KMO test and Bartlett's sphericity for 'Strategic Human Resources Management'

\begin{tabular}{|l|c|}
\hline \multicolumn{1}{|c|}{ Kaiser-Meyer-Olkin test for sampling adequacy } & 0.972 \\
\hline Barlett's test of sphericity - Approximated chi-squared & 1066.297 \\
\hline Barlett's test of sphericity - Degrees of Freedom & 78 \\
\hline Barlett's test of sphericity - Significance & 0.000 \\
\hline
\end{tabular}

Source: Research data (2017).

As for the analysis of inter-item correlation, the minimum value between the variables SHRM8 and SHRM24, presenting a value acceptable must be equal to or greater than 0.300 . The data equal to 0.524 and considered approved by this analysis. Table was favourable to this condition, with the lowest relation 8 shows the values for inter-item correlations.

Table 8 - Values for inter-item correlations for the construct 'Strategic Human Resources Management'

\begin{tabular}{|c|c|c|c|c|c|c|c|c|c|c|c|c|c|}
\hline \multicolumn{14}{|c|}{ Inter-itens Correlations } \\
\hline & SHRM8 & SHRM 21 & SHRM 22 & SHRM 23 & SHRM 24 & SHRM 25 & SHRM 26 & SHRM 27 & SHRM 28 & SHRM 29 & SHRM 30 & SHRM 31 & SHRM 32 \\
\hline SHRM8 & 1,000 & ,614 & ,639 & ,727 & ,524 & ,656 & ,687 & ,681 & ,637 & ,645 & ,660 & ,748 & ,583 \\
\hline SHRM21 & ,614 & 1,000 & 674 & ,735 & ,766 & ,735 & ,763 & ,806 & ,752 & ,683 & ,764 & ,759 & ,741 \\
\hline SHRM22 & ,639 & ,674 & 1,000 & ,854 & ,645 & ,722 & ,672 & ,698 & ,602 & ,705 & ,685 & ,640 & ,624 \\
\hline SHRM23 & ,727 & ,735 & ,854 & 1,000 & ,759 & ,810 & ,766 & ,752 & ,666 & 771 & ,765 & ,735 & ,706 \\
\hline SHRM24 & ,524 & ,766 & ,645 & 759 & 1,000 & ,805 & ,837 & ,768 & 602 & ,613 & 738 & 665, & 791 \\
\hline
\end{tabular}




\begin{tabular}{|c|c|c|c|c|c|c|c|c|c|c|c|c|c|}
\hline \multicolumn{14}{|c|}{ Inter-itens Correlations } \\
\hline & SHRM8 & SHRM 21 & SHRM 22 & SHRM 23 & SHRM 24 & SHRM 25 & SHRM 26 & SHRM 27 & SHRM 28 & SHRM 29 & SHRM 30 & SHRM 31 & SHRM 32 \\
\hline SHRM25 & ,656 & ,735 & ,722 & ,810 & ,805 & 1,000 & ,858 & ,827 & ,723 & ,850 & ,792 & 778 & ,733 \\
\hline SHRM26 & ,687 & ,763 & ,672 & ,766 & ,837 & ,858 & 1,000 & ,835 & 703 & ,683 & 753 & 701 & 774 \\
\hline SHRM27 & ,681 & ,806 & ,698 & ,752 & ,768 & ,827 & ,835 & 1,000 & ,832 & ,752 & 753 & 798 & ,693 \\
\hline SHRM28 & ,637 & ,752 & ,602 & ,666 & ,602 & ,723 & ,703 & ,832 & 1,000 & ,752 & 799 & ,793 & ,676 \\
\hline SHRM29 & ,645 & ,683 & ,705 & 771 & ,613 & ,850 & 683 & ,752 & ,752 & 1,000 & 783 & 773 & 614 \\
\hline SHRM30 & 660 & 764 & ,685 & ,765 & ,738 & 792 & 753 & 753 & 799 & 783 & 1,000 & ,846 & ,807 \\
\hline SHRM31 & ,748 & 759 & 640 & 735 & ,665 & 778 & 701 & 798 & 793 & 773 & ,846 & 1,000 & 684 \\
\hline SHRM32 & ,583 & ,741 & ,624 & ,706 & 791 & 733 & ,774 & ,693 & 676 & ,614 & ,807 & ,684 & 1,000 \\
\hline
\end{tabular}

As for the analysis for item-total correlation, the variables SHRM8, SHRM21; SHRM22; SHRM23; SHRM24; SHRM25; SHRM26; SHRM27; SHRM28; SHRM29; SHRM30; SHRM31 and SHRM32, are above 0.500 (minimum expected). The variable
SPM8, with a value equal to 0.742 , was approved by rounding and consistency in the other reliability tests. Table 9 shows the values for item-total correlations.

Table 9 - Values for Item-total correlations for the construct 'Strategic Human Resources Management'

\begin{tabular}{|c|c|c|c|c|c|}
\hline & $\begin{array}{l}\text { Average of } \\
\text { scale if the } \\
\text { Item for } \\
\text { Deleted }\end{array}$ & $\begin{array}{l}\text { Variance of } \\
\text { scale if the } \\
\text { Item for } \\
\text { Deleted }\end{array}$ & $\begin{array}{l}\text { Correlation } \\
\text { of total item } \\
\text { corrected }\end{array}$ & $\begin{array}{c}\text { Correlation } \\
\text { multiple to } \\
\text { square }\end{array}$ & $\begin{array}{l}\text { Alpha of } \\
\text { Cronbach is } \\
\text { Item for } \\
\text { Deleted }\end{array}$ \\
\hline SHRM8 & 54,53 & 259,818 & ,742 & ,703 & 971 \\
\hline SHRM 21 & 54,74 & 249,353 & ,848 & ,761 & 969 \\
\hline SHRM 22 & 54,36 & 258,987 & ,781 & ,751 & 971 \\
\hline SHRM 23 & 54,60 & 251,751 & ,871 & ,853 & ,969 \\
\hline SHRM 24 & 54,99 & 249,290 & ,820 & ,842 & 970 \\
\hline SHRM 25 & 54,67 & 250,427 & 901 & ,891 & ,968 \\
\hline SHRM 26 & 54,80 & 248,800 & ,873 & ,862 & 969 \\
\hline SHRM 27 & 54,61 & 245,168 & ,889 & ,866 & ,968 \\
\hline SHRM 28 & 54,61 & 253,371 & ,821 & ,809 & ,970 \\
\hline SHRM 29 & 54,60 & 247,751 & ,826 & ,826 & ,970 \\
\hline SHRM 30 & 54,54 & 251,324 & ,884 & ,856 & ,968 \\
\hline SHRM 31 & 54,31 & 253,755 & ,859 & ,837 & 969 \\
\hline SHRM 32 & 54,69 & 250,624 & ,809 & 761 & 970 \\
\hline
\end{tabular}

Source: Research data (2017).

In the analysis of the total variance explained, the value found was 74.988 in the first component. It surpassed, therefore, the minimum expected of $50 \%$, demonstrating that there is consistency of the measure. Table 10 shows the values for the total variance explained.

Table 10 - Values for total variance explained for the construct Strategic Human Resources Management

\begin{tabular}{|c|c|c|c|c|c|c|}
\hline & \multicolumn{3}{|c|}{ Initial eigenvalues } & \multicolumn{3}{|c|}{ loading squared sums extraction } \\
\hline & & $\%$ & $\%$ & & $\%$ & $\%$ \\
\hline & Total & Variance & cumulative & Total & Variance & Cumulative \\
\hline 1 & 9,748 & 74,988 & 74,988 & 9,748 & 74,988 & 74,988 \\
\hline 2 & ,672 & 5,169 & 80,157 & & & \\
\hline 3 &, 576 & 4,431 & 84,588 & & & \\
\hline 4 & ,419 & 3,213 & 87,802 & & & \\
\hline 5 & ,364 & 2,803 & 90,604 & & & \\
\hline 6 & ,330 & 2,536 & 93,140 & & & \\
\hline 7 & ,229 & 1,762 & 94,901 & & & \\
\hline 8 & 176 & 1,353 & 96,254 & & & \\
\hline 9 & ,130 & 1,001 & 97,255 & & & \\
\hline 10 & ,123 & ,945 & 98,200 & & & \\
\hline 11 & ,093 & ,712 & 98,913 & & & \\
\hline 12 & ,079 & ,606 & 99,519 & & & \\
\hline 13 & ,063 & 481 & 100,000 & & & \\
\hline
\end{tabular}


Finishing the tests needed for the exploratory factor analysis of the construct 'Strategic Human Resources Management', the unidimensionality test of the factor loading (' $n$ ' up to 200) was conducted. The variables SHRM8, SHRM21; SHRM22; SHRM23; SHRM24; SHRM25; SHRM26; SHRM27; SHRM28; SHRM29;
SHRM30; SHRM31 and SHRM32, are found in one single component, demonstrating its unidimensionality. In addition, the lowest factor loading is $\mathbf{0 . 7 7 9}$, (for the variable SHRM8), which is above the expected reference of 0.700 . Table 11 shows the test values of the main components.

Table 11 - Values for the main components for the construct Strategic Human Resources Management

\begin{tabular}{|c|c|c|c|c|c|c|c|c|c|c|c|c|c|c|c|c|c|c|c|}
\hline SHRM8 & SHRM21 & SHRM22 & SHRM23 & SHRM24 & SHRM25 & SHRM26 & SHRM27 & SHRM28 & SHRM29 & SHRM30 & SHRM31 & SHRM32 \\
\hline 0.779 & 0.871 & 0.813 & 0.893 & 0.847 & 0.916 & 0.893 & 0.907 & 0.848 & 0.856 \\
\hline
\end{tabular}

4.1.2 Exploratory Factor Analysis - Construct 'Hotel expected minimum (0.50). The lowest value was for HOP6 Performance' (0.497), which is acceptable in this test, by rounding. Table 12

For the communality test, the approved variables were HOP1, HOP2, HOP3, HOP4, HOP5 and HOP6, all of them above the shows the values for the communalities of each variable of the construct 'hotel performance'.

Table 12 - Communality - Construct 'Hotel Performance'

\begin{tabular}{|c|c|c|c|c|c|}
\hline HOP1 & HOP2 & HOP3 & HOP4 & HOP5 & HOP6 \\
\hline 0.810 & 0.828 & 0.762 & 0.724 & 0.767 & 0.497 \\
\hline
\end{tabular}

For the measure sampling adequacy (MSA), the variables approved were HOP1, HOP2, HOP3, HOP4, HOP5 and HOP6, all of them above the minimum expected $(0.50)$. The variable with the lowest value is HOP6 (0.807), for anti-image correlation, an acceptable value in this test. Table 13 shows the values for MSA for each variable.

Table 13 - Values for measure sampling adequacy for the construct 'Hotel Performance'

\begin{tabular}{|c|c|c|c|c|c|c|c|}
\hline \multirow{7}{*}{ Anti-image covariance } & & HOP1 & HOP2 & HOP3 & HOP4 & HOP5 & HOP6 \\
\hline & HOP1 & 224 &,- 096 & 002 &,- 005 &,- 043 & -153 \\
\hline & HOP2 & -,096 & 170 & -105 & ,018 & -,073 & ,041 \\
\hline & HOP3 & ,002 & -105 & ,231 &,- 131 & ,000 & ,040 \\
\hline & HOP4 &,- 005 & ,018 & -,131 & ,335 & -,077 & -,111 \\
\hline & HOP5 &,- 043 &,- 073 &,- 000 &,- 077 & ,322 & -,037 \\
\hline & HOP6 & -,153 & ,041 & -,040 &,- 111 & -,037 & ,490 \\
\hline \multirow{6}{*}{ Anti-image correlation } & HOP1 & ,845a &,- 491 & 009 &,- 016 & -160 &,- 461 \\
\hline & HOP2 &,- 491 & ,807ạ &,- 529 & -,075 &,- 312 & -,141 \\
\hline & HOP3 &,- 009 &,- 529 & ,826a &,- 471 & ,001 & 120 \\
\hline & HOP4 &,- 016 &,- 075 &,- 471 & ,864a &,- 234 &,- 274 \\
\hline & HOP5 & -,160 &,- 312 &,- 001 &,- 234 & ,929a &,- 094 \\
\hline & HOP6 &,- 461 & 141 & 120 &,- 274 &,- 094 & ,819a \\
\hline
\end{tabular}

Source: Research data (2017).

For the sample reliability test, the Cronbach's Alpha test was performed, where the minimum expected result is 0.700 . The standardised Cronbach's Alpha was 0.925 and approved in this test. Table 14 shows the values of Cronbach's Alpha and standardised Cronbach's Alpha.

Table 14 - Values for Cronbach's Alpha for the construct 'Hotel Performance'

\begin{tabular}{|c|c|c|}
\hline Cronbach's Alpha & Standardised Cronbach's Alpha & Number of Items \\
\hline 0.923 & 0.925 & 6 \\
\hline
\end{tabular}

For the Kaiser-Meyer-Olkin (KMO) test, the value found was 0.847 , which is above the minimum expected $(0.50)$. The significance was lower than 0.05 , which is approved by these tests. Table 15 shows the values for KMO test and Bartlett's sphericity.

Table 15 - Values for KMO test and Bartlett's sphericity for 'Hotel Performance'

Kaiser-Meyer-Olkin test for sampling adequacy

Barlett's test of sphericity - Approximated chi-squared

Barlett's test of sphericity - Degrees of Freedom

Barlett's test of sphericity - Significance

0.847
338.194
15
0.000

0.000

Source: Research data (2017). 
As for the analysis of inter-item correlation, the minimum acceptable value for inter-item relation must be equal to or greater than 0.300 . The data obtained was favourable to this condition, with the lowest relation between the variables HOP3 and HOP6 (0.436), therefore approved by this analysis. Table 16

shows the values for inter-item correlations.

Table 16 - Values for inter-items correlations for the construct 'Hotel Performance'

\begin{tabular}{|c|c|c|c|c|c|c|}
\hline & HOP1 & HOP2 & HOP3 & HOP4 & HOP5 & HOP6 \\
\hline HOP1 & 1,000 & ,824 & 702 & 661 & ,747 & 667 \\
\hline HOP2 & ,824 & 1,000 &,- 835 & 683 &,- 781 & 493 \\
\hline HOP3 & 702 & ,835 & 1,000 & 759 & 700 & ,436 \\
\hline HOP4 & 661 & 683 &,- 759 & 1,000 & 692 & ,566 \\
\hline HOP5 & 747 &,- 781 &,- 700 & 692 & 1,000 & ,545 \\
\hline HOP6 & ,667 & ,493 &,- 436 & ,566 & ,545 & 1,000 \\
\hline
\end{tabular}

Source: Research data (2017).

As for the analysis for item-total correlation, all variables are above 0.500 , the minimum expected. The variable HOP6, with a value equal to 0.631 , was approved for being above the minimum expected. Table 17 shows the values for item-total correlations.

Table 17 - Values for item-total correlations for the construct 'Hotel Performance'

\begin{tabular}{|c|c|c|c|c|}
\hline & $\begin{array}{c}\text { Average of } \\
\text { scale if the } \\
\text { Item for } \\
\text { Deleted }\end{array}$ & $\begin{array}{c}\text { Variance of } \\
\text { scale if the } \\
\text { Item for } \\
\text { Deleted }\end{array}$ & $\begin{array}{c}\text { Alpha of } \\
\text { Correlation } \\
\text { of total item } \\
\text { corrected } \\
\text { Item for } \\
\text { Deleted }\end{array}$ & $\begin{array}{c}\text { Correlation } \\
\text { multiple to } \\
\text { square }\end{array}$ \\
\hline HOP1 & 17,50 & 19,993 &, 853 &, 776 \\
\hline HOP2 & 17,49 & 21,123 &, 851 &, 830 \\
\hline HOP3 & 17,71 & 22,439 &, 796 &, 769 \\
\hline HOP4 & 17,60 & 22,794 &, 778 &, 665 \\
\hline HOP5 & 17,53 & 22,253 &, 811 &, 678 \\
\hline HOP6 & 17,17 & 22,869 &, 613 &, 510 \\
\hline
\end{tabular}

Source: Research data (2017).

In the analysis of the total variance explained, the first component presented $73.131 \%$. It surpassed, therefore, the recommended minimum of $50 \%$, demonstrating that there is consistency of the measure. Table 18 shows the values for the total variance explained.

Table 18 - Values for total variance explained for the construct 'Hotel Performance'

\begin{tabular}{|c|c|c|c|c|c|c|}
\hline & \multicolumn{3}{|c|}{ Initial eigenvalues } & \multicolumn{3}{|c|}{ loading squared sums extraction } \\
\hline & & $\%$ & $\%$ & & $\%$ & $\%$ \\
\hline & Total & Variance & cumulative & Total & Variance & cumulative \\
\hline 1 & 4,388 & 73,131 & 73,131 & 4,388 & 73,131 & 73,131 \\
\hline 2 & ,654 & 10,905 & 84,036 & & & \\
\hline 3 & ,392 & 6,537 & 90,574 & & & \\
\hline 4 & 281 & 4,686 & 95,260 & & & \\
\hline 5 & 177 & 2,943 & 98,203 & & & \\
\hline 6 & 108 & 1,797 & 100,000 & & & \\
\hline
\end{tabular}

Finishing the tests needed for exploratory factor analysis of the single component, demonstrating its unidimensionality. Also, construct 'Hotel Performance', the unidimensionality test and the factor loading (' $n$ ' up to 200) was conducted. The variables HOP1, HOP2, HOP3, HOP4, HOP5 and HOP6 are found in one the lowest factor loading is 0.705 (for the variable HOP6), which is above the expected reference of 0.700 . Table 19 shows the test values of the main components.

Table 19 - Values of the tests of the main components for the construct 'Hotel Performance'

\begin{tabular}{|l|l|l|l|l|l|}
\hline HOP1 & HOP2 & HOP3 & HOP4 & HOP5 & HOP6 \\
\hline 0.900 & 0.910 & 0.873 & 0.851 & 0.876 \\
\hline
\end{tabular}


4.2

\section{Confirmatory Factor Analysis}

\subsubsection{Confirmatory Factor Analysis - Construct 'Strategic Human Resources Management'}

Based on the analysis of the exploratory data, Figure 1 illustrates the model proposed in this article. The model assumes that SHRM is significantly related to the variables 'Promoting creativity in pursuing continuous improvement', 'Promoting variable remuneration in the long term', 'Developing effective and transparent communication', 'Preparing the organisation to face future challenges', 'Implementing or restructuring processes of salary and benefits', 'Identifying and implementing best practices in SHRM', 'Facilitating organisational changes', 'Recognising and rewarding people', 'Stimulating delegation and autonomy (empowerment)', 'Promoting diversity and inclusion', 'Promoting knowledge management', 'Promoting and supporting employees' initiatives', and 'Investing in the development of new technology and working methods'.

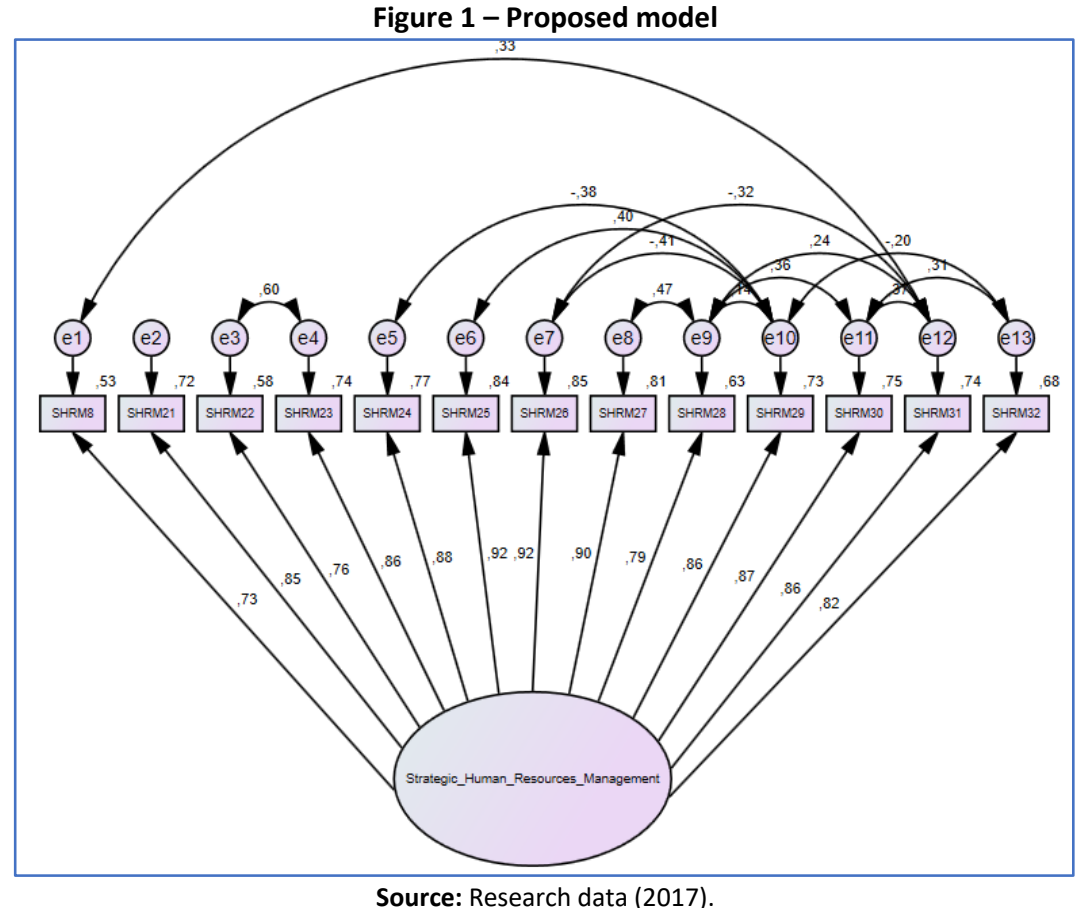

Table 20 shows the regression coefficients and the significance regression coefficients always higher than 0.6 and statistical test of the model's variables. It is possible to observe that significance in all the variables of the exploratory analysis.

Table 20 - Standardized regression coefficients and significance test

\begin{tabular}{|c|c|c|c|c|c|c|c|c|c|c|c|c|c|}
\hline & SHM8 & SHRM21 & SHRM22 & SHRM23 & SHRM24 & SHRM25 & SHRM26 & SHRM27 & SHRM28 & SHRM29 & SHRM30 & SHRM31 & SHRM32 \\
\hline Coefficient & 0.728 & 0.726 & 0.605 & 0.862 & 0.876 & 0.918 & 0.921 & 0.898 & 0.791 & 0.856 & 0.867 & 0.605 & 0.824 \\
\hline $\mathbf{P}$ & 0.000 & 0.000 & 0.000 & 0.000 & 0.000 & 0.000 & 0.000 & 0.000 & 0.000 & 0.000 & 0.000 & 0.000 & 0.000 \\
\hline
\end{tabular}

Source: Research data (2017).

Table 21 shows the adjustment indexes of the general model of adherence of the proposed model and the understanding of its measurement. These tests were carried out to improve validity.

Table 21 - Adjustment indexes of the general model of measurement - Construct 'Strategic Human Resources Management'

\begin{tabular}{|c|c|c|}
\hline Index & Final Value & Expected Value \\
\hline$X^{2}$ & $186.966(\mathrm{DF}=131)$ & \\
\hline $\mathrm{X}^{2} / \mathrm{DF}$ & 1.427 & $<3,000$ \\
\hline $\mathrm{P}$ & 0.001 & $<0,050$ \\
\hline RMSEA & 0.079 & $<1,000$ \\
\hline $\mathrm{CFI}$ & 0.962 & $>0,900$ \\
\hline TLI & 0.950 & $>0,900$ \\
\hline $\mathrm{NFI}$ & 0.901 & $>0,900$ \\
\hline
\end{tabular}

Source: Research data (2017). 
4.2.2 Confirmatory Factor Analysis - Construct 'Hotel Performance'

approved, and the variable HOP6 was the lowest (0.519), above the minimum expected, as shown in Table 22.

According to Hair et al. (2009), 0.500 is considered the lowest value accepted to standardised loading. All variables were

Table 22 - Standardized coefficients and significance test

\begin{tabular}{|c|c|c|c|c|c|c|}
\hline & HOP1 & HOP2 & HOP3 & HOP4 & HOP5 & HOP6 \\
\hline Coefficient & 0.852 & 0.967 & 0.857 & 0.796 & 0.820 & 0.519 \\
\hline $\mathbf{P}$ & 0.000 & 0.000 & 0.000 & 0.000 & 0.000 & 0.000 \\
\hline
\end{tabular}

Source: Research data (2017).

Regarding the variables of the construct HOP the proposed model considers: HOP1 - Total sales; HOP2 - Average occupancy rate; HOP3 - Profit margin on total sales; HOP4 - Average daily rate; HOP5 - Sales per unit; HOP6 - Average cost per occupied room, as shown in Figure 2.

\section{Figure 2 - Model for the construct 'Hotel Performance'}

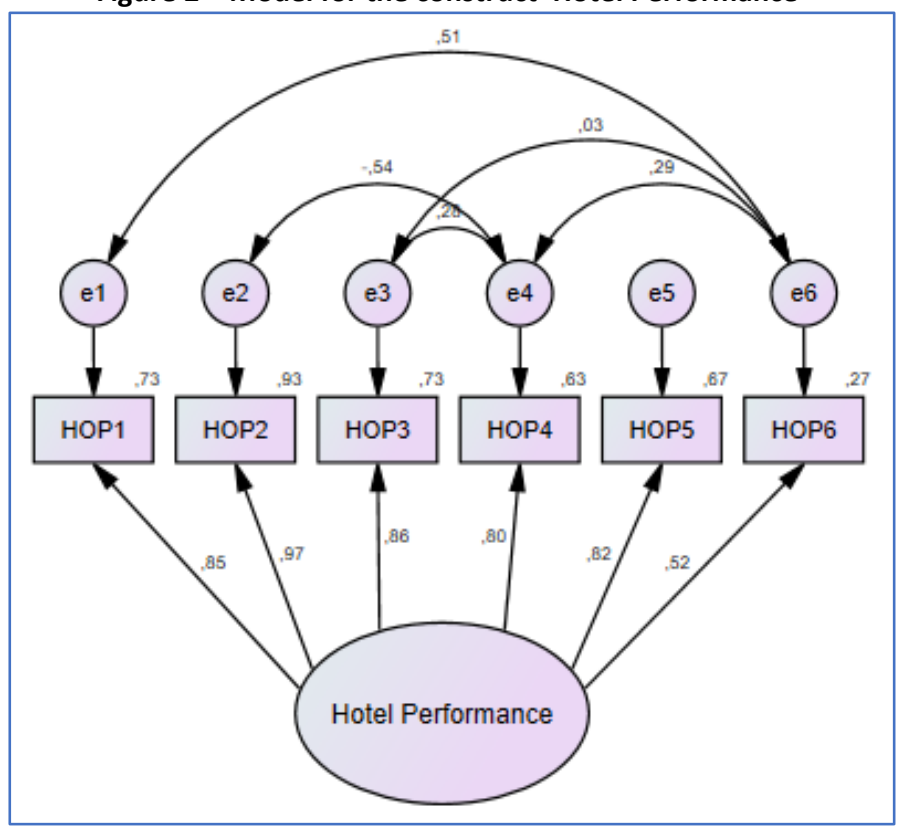

Source: Research data (2017).

Table 23 shows the Adjustment indexes of the general model of improve adherence of the proposed model and the measurement - Construct HOP. These tests were carried out to

understanding of its validity.

Table 23 - Adjustment indexes of the general model of measurement - Construct 'Hotel Performance.'

\begin{tabular}{|c|c|c|}
\hline Index & Final Value & Expected Value \\
\hline $\mathrm{X}^{2}$ & $5.960(\mathrm{DF}=4)$ & \\
\hline $\mathrm{X}^{2} / \mathrm{DF}$ & 1.490 & $<3.000$ \\
\hline $\mathrm{P}$ & 0.202 & $>0.050$ \\
\hline $\mathrm{RMSEA}$ & 0.084 & $<0.100$ \\
\hline $\mathrm{CFI}$ & 0.994 & $>0.900$ \\
\hline $\mathrm{TLI}$ & 0.978 & $>0.900$ \\
\hline $\mathrm{NFI}$ & 0.983 & $>0.900$ \\
\hline
\end{tabular}

Source: Research data (2017).

\subsection{Structural Model}

After approval of the variables for the constructs Strategic
Human Resources Management Strategies (SHRM) and Hotel Performance (HOP), structural equations modelling was conducted with the following results (Figure 3 ): 


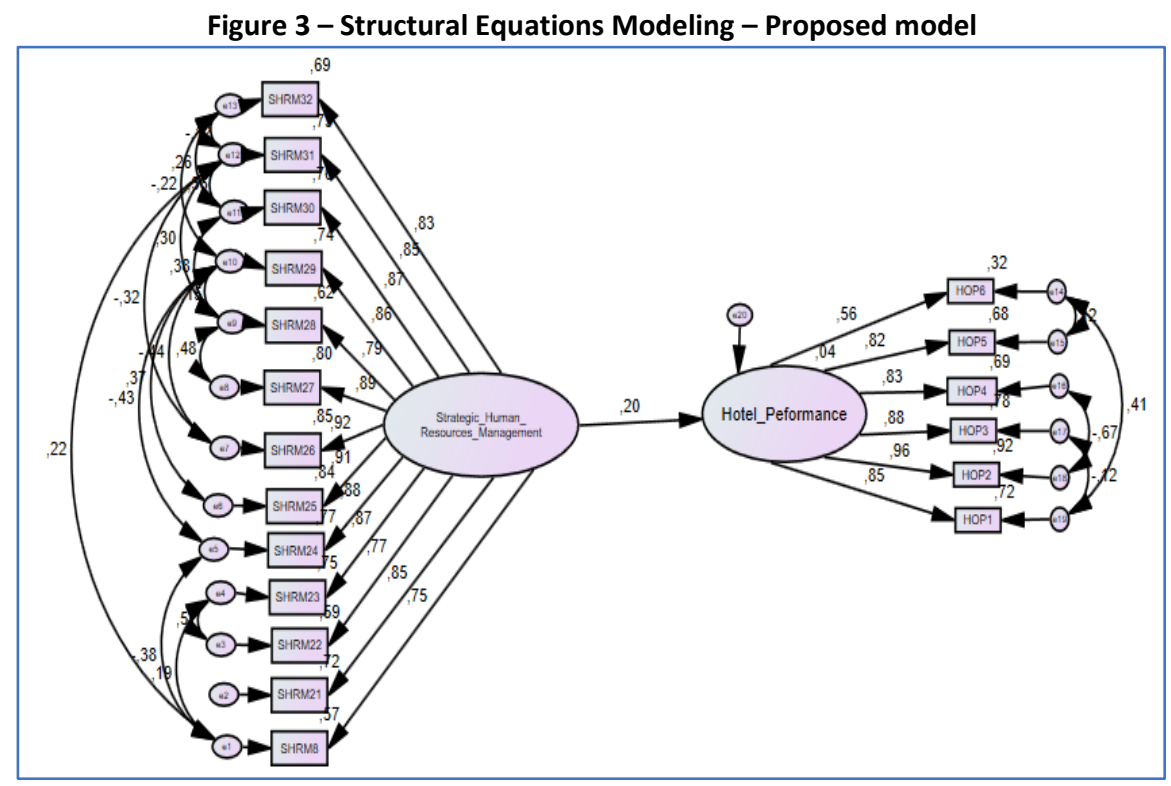

Source: Research data (2017).

Table 24 presents the results obtained in the proposed model. the root mean square error of approximation (RMSEA) are In terms of the absolute adjustment, the values of chi-squared found as expected. As for the incremental adjustment, the $\left(X^{2}\right)$; chi-squared divided by the degrees of freedom ( $\left.X^{2} / D F\right)$ and

values are above the expected value.

\begin{tabular}{c|c|c|}
$\begin{array}{c}\text { Table 24 - Adjustment indexes of the general model of measurement - Proposed model } \\
\text { Index }\end{array}$ & $\begin{array}{c}\text { Final Value } \\
\text { Expected Value }\end{array}$ \\
\hline$X^{2}$ & $186.966(\mathrm{DF}=131)$ & \\
\hline $\mathrm{X}^{2} / \mathrm{DF}$ & 1.427 & $<3,000$ \\
\hline P & 0.001 & $<0,050$ \\
\hline RMSEA & 0.079 & $<1,000$ \\
\hline CFI & 0.962 & $>0,900$ \\
\hline TLI & 0.950 & $>0,900$ \\
\hline NFI & 0.901 & $>0,900$ \\
\hline
\end{tabular}

Source: Research data (2017).

The tested variables were approved and their standardized the values of each tested variable. coefficients and with statistical significance. Table 25 presents

Table 25 - Standardized coefficients and significance test

\begin{tabular}{|c|c|c|c|c|c|c|c|c|c|c|c|c|c|}
\hline & $\begin{array}{c}\text { SHRM } \\
8\end{array}$ & $\begin{array}{c}\text { SHRM } \\
21\end{array}$ & $\begin{array}{c}\text { SHRM } \\
22\end{array}$ & $\begin{array}{c}\text { SHRM } \\
23\end{array}$ & $\begin{array}{c}\text { SHRM } \\
24\end{array}$ & $\begin{array}{c}\text { SHRM } \\
25\end{array}$ & $\begin{array}{c}\text { SHRM } \\
26\end{array}$ & $\begin{array}{c}\text { SHRM } \\
27\end{array}$ & $\begin{array}{c}\text { SHRM } \\
28\end{array}$ & $\begin{array}{c}\text { SHRM } \\
29\end{array}$ & $\begin{array}{c}\text { SHRM } \\
\mathbf{3 0}\end{array}$ & $\begin{array}{c}\text { SHRM } \\
\mathbf{3 1}\end{array}$ & $\begin{array}{c}\text { SHRM } \\
32\end{array}$ \\
\hline Coefficient & 0.728 & 0.726 & 0.605 & 0.862 & 0.876 & 0.918 & 0.921 & 0.898 & 0.791 & 0.856 & 0.867 & 0.605 & 0.824 \\
\hline \multirow[t]{2}{*}{$\mathrm{P}$} & 0.000 & 0.000 & 0.000 & 0.000 & 0.000 & 0.000 & 0.000 & 0.000 & 0.000 & 0.000 & 0.000 & 0.000 & 0.000 \\
\hline & HOP1 & HOP2 & HOP3 & HOP4 & HOP5 & HOP6 & & & & & & & \\
\hline Coefficient & 0.852 & 0.967 & 0.857 & 0.796 & 0.820 & 0.519 & & & & & & & \\
\hline P & 0.000 & 0.000 & 0.000 & 0.000 & 0.000 & 0.000 & & & & & & & \\
\hline
\end{tabular}

Source: Research data (2017).

The model proposed supported the hypothesis, presenting a Hotel Performance for medium size hotels in Greater positive standardised loading Strategic Strategic Human Florianópolis. Table 26 shows the standardised loading, CR and Resources Management, with positive relationships in terms of significance.

Table 26 - Loading estimates of the structural model

\begin{tabular}{|l|c|c|c|c|}
\hline & Standardised loading & C.R. & P \\
\hline HOP & SPM & 0.108 & 1.438 & 0.000 \\
\hline
\end{tabular}

Source: Research data (2017). 


\section{Conclusion}

This study sought to verify the relation of Strategic Human Resources Management and the performance in the hotel industry. It gathered data that allowed to build a conceptual model in which SHRM affects hotel performance (HOP), collaborating to fill a gap in studies in the area of SHRM in Brazil. It gathered data that allowed to build a conceptual model in which Strategic Human Resources Management affects hotel performance, collaborating to fill a gap in studies in the area of Strategic Human Resources Management in the region of Greater Florianópolis, in Brazil.

Through research applied in medium-sized hotels in the region of Greater Florianópolis, it was possible to observe a set of variables, both of Strategic Human Resources Management and in terms of hotel performance, transforming abstract concepts into empirical and measurable variables.

When pursuing the research objective, some difficulties were found and overcome, imposed by the process itself. Among them the unavailability of the managers of hotels visited by the researcher, who refused to participate, which may indicate that the reality of work of the managers in the hotel industry is exhaustive and creates obstacles in organising their schedule. In addition, there is a lack of knowledge about the importance of contributing to scientific research, a fact that generates discomfort and distrust on the part of the interviewee.

Empirical scientific research enables the production of knowledge, transforming concepts into indicators, which was enabled by the factor analysis.

This study used scales already validated for both constructs. Strategic Human Resources Management was validated by Barreto (2011) and Hotel Performance by Carvalho (2011). The proposed model built from these validated scales proved to be effective for verifying the relationship between the two constructs, and allowed to confirm the hypothesis presented in this research.

Thus, the two constructs could be investigated through Exploratory Factor Analysis (EFA) and Confirmatory Factor Analysis (CFA).

The several observed variables of strategic Strategic Human Resources Management could be reduced from 32 to 13, making the model parsimonious while being explanatory.

In the construct 'Hotel Performance' variables were validated, demonstrating the adequacy of the data and how they are representative of the construct. Therefore, total sales, average occupancy rate, profit margin on total sales, average daily rate, sales per unit, and the average cost per occupied room are explanatory factors. They represent the latent dimensions (constructs) that explain the set of observed variables.

The practices of Strategic Human Resources Management could be observed and even hierarchized from the extracted factors. Most of them pointed to education, training and development of employees as the main influencer of hotel performance. In the case of medium-sized hotels in Greater Florianópolis, Brazil, in order to achieve good hotel performance, the important strategies are promoting creativity in pursuing continuous improvement, preparing the organization to face future challenges, stimulating delegation and autonomy (empowerment), promoting knowledge management, investing in development of new technology and working methods.

In addition, structuring a suitable workplace for the health and well-being of employees has proved to be an important strategic decision for performance. More specifically in the hotels studied, it can be observed that developing transparent and effective communication, identifying and implementing best practices in Strategic Human Resources Management, facilitating organisational changes, and promoting knowledge management are measures that promote this desired work environment.

The work of Southgate and Mondo (2017) obtained results are similar to those found here. When researching the job satisfaction of Florianópolis hotel employees, the authors concluded that the level of job satisfaction of workers is indifferent (neither satisfied nor dissatisfied. In addition, they expressed greater dissatisfaction about the salary dimension and more satisfaction with the managerial dimension. The correlation between Work Satisfaction and Distributive Justice was positive, concluding that it is possible to improve satisfaction in the medium and long term with specific actions.

On the other hand, none of the factors revealed by the research put performance appraisal as a practice that directly influences hotel performance.

It is possible to say that although recruitment and selection activity is very important for the management of people - as pointed out in the theoretical framework- out of the factors extracted, only one of them has a connection with this practice: promoting diversity and inclusion.

The factors 'implementing or restructuring processes of salary and benefits' and 'recognising and rewarding people', emphasise the importance of the two activities of Strategic Human Resources Management to obtain excellent hotel performance, which are: job structuring and remuneration policies, and benefits.

Considering the theoretical framework presented in this study and the research carried out with the medium-sized hotels in the region of Greater Florianópolis, Brazil, it is possible to say that the objective of the work was fully achieved, building a structural model that supports the hypothesis that there is a relationship between strategic Strategic Human Resources Management and hotel performance.

For further research on the topic of Strategic Human Resources Management in the Hotel Industry, it is recommended the investigation of the Strategic Human Resources Management construct, as a mediator of the relationship with other constructs, and hotel performance. Studies that used the construct marketing's dynamic capacity, being mediated by the differentiation constructs of services, in the dimension of 
people (Castro Júnior, 2013) or the dynamic capacity of innovation (Deluca, 2017) support such hypotheses. It is also recommended for future research guidelines the analysis of predecessors to Strategic Human Resource, such as Organizational culture, analysing if it has an influence on the construct in a predictive way. Withal, it is suggested that the external environment construct is also considered in the model.

\section{References}

Araujo, A. O. (2001) Contribuição ao Estudo de Indicadores de Desempenho de Empreendimentos Hoteleiros, sob o Enfoque da Gestão Estratégica. Tese de Doutorado. Tese (Doutorado em Administração) Programa de Pós-Graduação em Administração, São Paulo: Universidade de São Paulo.

Araújo, L. C. G. \& Garcia, A. A. (2009). Gestão de pessoas: estratégias e integração organizacional. São Paulo: Atlas.

Assis, F. A. A. (2009) Práticas de gestão de pessoas no setor hoteleiro de Juiz de Fora-MG. Brasília: Universidade de Brasília.

Barreto, L. M. T. S. (2011) Estratégias de gestão de pessoas e desempenho organizacional na hotelaria: o papel das capacidades organizacionais. Tese de Doutorado. Tese (Doutorado em Administração) Programa de Pós-Graduação em Administração, São Paulo: Universidade de São Paulo.

Barreto, L. M. T. S., Albuquerque, L. G. \& Medeiros, C. A. F. (2014). Estratégias de gestão de pessoas e desempenho organizacional na hotelaria: o papel das capacidades organizacionais. Revista Brasileira de Pesquisa em Turismo, 8(2), 340-360.

Barretto, A. I. (2007). As contribuições das relações públicas para a comunicação mercadológica hoteleira: a rede Plaza de Hotéis, Resorts \& Spas Brasil. Revista da Graduação, 1(1), 1-144.

Barros, M. O., Silva, S. C., Granero, A. E. \& Braga Filho, H. (2008). O Desenvolvimento do Turismo: Uma visão sistêmica. In: $4^{\circ}$ Congresso Brasileiro de Sistemas, (pp. 1-17), Franca, SP: Uni-facef.

Bolgar, P. H. (2001). Gestão do conhecimento e o capital humano: onde tudo começa. Retrieved 28.01.2018 from: http://www.rh.com.br/Portal/Desenvolvimento/Artigo/3168/gestaodo-conhecimento-e-o-capital- humano-onde- tudo-comeca.html

Aryee, S., \& Budhwar, P. (2008). Human resource management and organizational performance. In M. J. R. Butler (Ed.), Strategic human resource management: building research-based perspective (pp. 191212). London (UK): CIPD.

Camargos, M. A. \& Dias, A. T. (2010). Estratégia, administração estratégica e estratégia corporativa: uma síntese teórica. REGE Revista de Gestão, 10(1), 27-39.

Campos, L. C. D. A. M. \& Gonçalves, M. H. B. (1998). Introdução a turismo e hotelaria. Rio de Janeiro: Senac.

Carvalho, F. M. R., Miura, M. N. \& Ribeiro, I. (2017) Fanpages de hotéis: fatores de gratificação e satisfação que motivam o acesso dos usuários. Hospitalidade Revista da Universidade Anhembi, 14(1), 1-23.

Castro Júnior, D. F. L. (2013). Estratégias para a hotelaria executiva catarinense: uma análise entre as capacidades mercadológicas, diferenciação de serviços e desempenho. Tese de Doutorado, Programa de Pós-Graduação em Administração e Turismo, Biguaçu, SC: Universidade do Vale do Itajaí.

Castro Júnior, D. F. L., Gonçalo, C. R., Rossetto, C. R. \& Deluca, M. A. (2016). Estudo dos reflexos das capacidades mercadológicas no desempenho da hotelaria executiva em Santa Catarina. Faces: Revista de Administração, 15(1), 44-63.

Castro Júnior, D. F. L., Gonçalo, R. C., Rossetto, C. R. (2014). Diferenciação de senviços: construção e validação de escalas. Faces: Revista de Administração, 13(1), 46-64.

CECCA - Centro de Estudos Cultura e Cidadania (1997). Uma cidade numa ilha. Editora Insular: Florianópolis, Santa Catarina.

Corrêa, C. C., Mariani, M., Veloso, A. F. \& Satolani, M. F. (2011) Avaliação da cadeia produtiva do turismo no Estado de Mato Grosso do
Sul: Região dos Lagos. Gepros: Gestão da Produção, Operações e Sistemas, 6(2), 33-55.

Creswell, J. W. (2010). Projeto de pesquisa: métodos qualitativo, quantitativo e misto. Porto Alegre: Artmed/Bookman.

Deluca, M. A. M. (2017) Influência da capacidade inovativa e da diferenciação de serviços no desempenho: um estudo nos supermercados em Santa Catarina. Tese de Doutorado. Tese (Doutorado em Administração e Turismo) Programa de Pós-Graduação em Administração e Turismo, Biguaçu, SC: Universidade do Vale do Itajaí.

DIEESE, Departamento Intersindical de Estatística e Estudos Socioeconômicos (2013). Estudo do setor Hoteleiro/Departamento Intersindical de Estatística e Estudos Socioeconômicos. São Paulo: CUTCONTRASC.

Echeverria, E. L., Crepaldi, M. L. S. \& Bianchi, E. (2017). O recrutamento, seleção e treinamento e seu impacto no desempenho da função na linha de produção, Revista Faipe, 3(1), 7-15.

Ferreira, A. C. (2013). Políticas e Práticas de Gestão de Recursos Humanos na Hotelaria da Ilha da Madeira. Retrieved 12.05.2018 from http://hdl.handle.net/1822/25154

Floripa, Amanhã (2017). Censo mapeia setor de hotelaria e gastronomia de Florianópolis. $\quad$ Retrieved 22.01.2018 from http://floripamanha.org/2016/06/censo-mapeia-setor-de-hotelaria-egastronomia-de-florianopolis/

Fonseca, J. J. S. (2002) Metodologia da pesquisa científica. Fortaleza: UEC.

Freitas, H., Oliveira, M., Saccol, A. Z. \& Moscarola, J. (2000). O método de pesquisa survey. Revista de Administração, 35(3), 105-112.

Garcia, A. G. A. (2016). Gestão de Recursos Humanos na Indústria do Turismo em Portugal: Tendências Futuras do Capital Humano: um estudo exploratório em unidades hoteleiras no Distrito de Coimbra. Tese de Doutorado. $\quad$ Retrieved 14.12 .2017 from http://hdl.handle.net/10400.22/7690

Gheno, R. \& Berlitz, J. B. (2011). Remuneração Estratégica e Pacote de Benefícios: um estudo de caso aplicado ao nível operacional de uma multinacional. Brazilian Journal of Management, 4(1), 268-287.

Hair, J. F., Anderson, R. E., Tatham, R. L. \& Black, W. (2009). Análise multivariada de dados. 5a ed. São Paulo: Bookman.

IBGE - Instituto Brasileiro de geografia e estatística. Pesquisa de serviços de hospedagem - PSH. Retrieved 14.01.2017 from http://www.ibge.gov.br/home/estatistica/economia/comercioeservic o/psh/2011/comentarios.pdf

Lacombe, F. (2004). Dicionário de administração. São Paulo: Saraiva.

Lanziotti, T. M. (2008). Planejamento turístico e urbanização na cidade de Florianópolis: um estudo de Jurerê Internacional. 2008. Monografia, Florianópolis: Universidade Federal de Santa Catarina.

Meyer, J. T. (2008). O Turismo como fenômeno social de inversão. Revista da Graduação, 1(1), 1-68.

Mondo, T. S. \& Fiates, G. G. S. (2017). TOURQUAL: proposal of a protocol for quality evaluation on services at tourist attractions. Brazilian Business Review, 14(4), 448-465.

MTUR (2017a) Ministério do Turismo. Marcos Conceituais. Retrieved 17.05.2018 from http://www.turismo.gov.br/sites/default/turismo/o_ministerio/public acoes/downloads_publicacoes/Marcos_Conceituais.pdf

MTUR (2017b) Ministério do Turismo. Websérie mostra impacto positivo da hotelaria na economia do País. Retrieved 17.05.2018 from http://www.brasil.gov.br/turismo/2017/02/webserie-mostra-impactopositivo-da-hotelaria-na-economia-do-pais

Nichele, J., Stefano, S R. \& Raifur, L. (2015). Análise da remuneração estratégica para atrair e reter colaboradores: a visão dos pósgraduandos. Revista de Carreiras e Pessoas, 5(2), 212-231.

OMS - Organização Mundial da Saúde. (2010). Ambientes de trabalho saudáveis: um modelo para ação: para empregadores, trabalhadores, formuladores de política e profissionais. /OMS; tradução do Serviço 
Social da Indústria. Brasília: SESI/DN.

OMT - Organização Mundial do Turismo. (2017a). Why Tourism. Retrieved 17.05.2018 from http://www2.unwto.org/content/whytourism

OMT - Organização Mundial do Turismo. (2017b). Panorama OMT del Turismo Internacional. Retrieved 17.05.2018 from http://www.eunwto.org/doi/pdf/10.18111/9789284418152

Petrocchi, M., (2002). Hotelaria: planejamento e gestão. São Paulo: Futura.

Pimentel, H. (2016). O papel da gestão de pessoas no turismo. Revista Lusófona de Economia e Gestão das Organizações, 4, 81-111.

Santos, J. A. \& Estender, A. C. (2016). Qualidade de vida e o impacto na rotatividade no setor hoteleiro. Revista FATEC Guarulhos: Gestão, Tecnologia \& Inovação, 2(1), 82-95.

SEBRAE - Serviço Brasileiro de Apoio às Micro e Pequenas Empresa (2010). Turismo no Brasil: Termo de referência para a atuação do Sistema SEBRAE 2010. Retrieved 17.05.2018 from http://intranet.df.sebrae.com.br/download/uam/Pesquisa/Turismo/T R_turismo_final.pdf

SEBRAE - Serviço Brasileiro de Apoio às Micro e Pequenas Empresa (2013). Santa Catarina em Números: Macrorregião Grande Florianópolis / Sebrae/SC. Florianópolis: Sebrae/SC.

Southgate, N. N. A. \& Mondo, T. S. (2017). Perceptions of job satisfaction and distributive justice: $A$ case of Brazilian F\&B hotel employees. Turizam: znanstveno-stručni časopis, 65(1), 87-101.

WTTC - World Travel \& Tourism Council. (2017). Economic Impact 2017 Brazil. Retrieved 17.05.2018 from https://www.wttc.org//media/files/reports/economic-impact-research/countries-

2017/brazil2017.pdf

Received: 15.02.2018

Revisions required: 18.07 .2018

Accepted: 20.11.2018 